\title{
Genetic signatures of rafting dispersal in algal-dwelling brooders Limnoria spp. (Isopoda) along the SE Pacific (Chile)
}

\author{
Pilar A. Haye ${ }^{1, *}$, Andrea I. Varela $^{1,2}$, Martin Thiel ${ }^{1}$ \\ ${ }^{1}$ Departamento de Biología Marina, Facultad de Ciencias del Mar, Universidad Católica del Norte, Larrondo 1281, \\ and Centro de Estudios Avanzados en Zonas Áridas (CEAZA), Coquimbo, Chile \\ ${ }^{2}$ Present address: School of Biological Sciences, Victoria University of Wellington, Wellington, New Zealand
}

\begin{abstract}
Brooding marine isopods of the genus Limnoria inhabit and feed on kelp holdfasts and wood. These substrata have high floating potential, making these species ideal organisms to study the effects of rafting-mediated connectivity on the population structure of brooders living on rafting substrata. It is hypothesized that rafting leaves particular genetic signatures such as low differentiation among distant local populations and absence of isolation by distance (IBD) at a macro-geographic scale (thousands of $\mathrm{km}$ ). Using cytochrome oxidase I (COI) sequences, we tested the effects of rafting-mediated gene flow with respect to genetic differentiation on L. quadripunctata (from wood and also the holdfasts of the giant kelp Macrocystis pyrifera) and $L$. chilensis (mainly from the bull kelp Durvillaea antarctica) sampled across $2400 \mathrm{~km}$ of the Chilean coast. Analyses of COI data for both species indicated low differentiation between distant locations along the Chilean coast and lack of IBD, bearing the expected genetic signatures of rafting dispersal. Phylogenetic analyses were performed with COI and the nuclear gene $28 \mathrm{~S}$ to place the genetic diversity of Chilean Limnoria spp. into a wider geographical context. Both markers revealed that $L$. quadripunctata from Chile is a sister clade to other Limnoria spp. analyzed ( $L$. chilensis, L. segnis, and L. stephenseni), which mainly inhabit D. antarctica. L. chilensis from Chile and subantarctic islands form a tight monophyletic group. Phylogenetic and phylogeographic analyses show that along the studied area, $L$. quadripunctata and L. chilensis have the genetic signatures of relatively recent or ongoing rafting.
\end{abstract}

KEY WORDS: Peracarids · Rafting · Biogeography $\cdot$ Mitochondrial DNA $\cdot$ COI $\cdot 28 \mathrm{~S} \cdot$ Phylogeny Phylogeography

Resale or republication not permitted without written consent of the publisher

\section{INTRODUCTION}

While benthic marine brooding species lack a larval dispersal stage, they may have even wider geographic distributions than sympatric congeners with planktonic larvae (Thiel \& Haye 2006). For example, Rockall Island in the North Atlantic has been colonized by the brooding snail Littorina saxatilis, but not by its broadcast-spawning congener L. littorea, which has a pelagic larval stage lasting $4 \mathrm{wk}$ (Johannesson 1988). While the duration of larval stages is frequently used as a valuable proxy for potential dis- persal distances (Jablonski \& Lutz 1983, Díaz 1995, Grantham 1995, but see Lester et al. 2007), the prediction of dispersal distances for direct developers is more complicated. One of the most important natural mechanisms of passive dispersal for benthic organisms is rafting on floating algae or other objects (Helmuth et al. 1994, Ingólfsson 1995, Hobday 2000). Passive dispersal of brooders over long distances depends on the stochastic transport of juveniles and/or adults on discrete patches of rafting material. Organisms traveling on floating algae have a high potential to be dispersed over long distances and col- 
onize new geographic areas or maintain population connectivity with distant areas (e.g. Waters \& Roy 2004, Donald et al. 2005, Fraser et al. 2009, 2011, Nikula et al. 2010). Such individuals may form colonizing or founder groups over a wide range of distances, including isolated localities (Johannesson 1988, Cunningham \& Collins 1998).

Based on the rafting hypothesis, Johannesson (1988) proposed that colonization success would be higher for taxa that brood offspring than for planktonic developers, as she had observed in Rockall with Littorina species. Organisms that live and feed on their raft may persist throughout the voyage, including brooding females, whose juveniles recruit nearby and experience extended parental care. These features increase the probability of long-distance dispersal and successful colonization (Davenport \& Stevenson 1998, Thiel \& Haye 2006).

Species with a low potential for autonomous dispersal (such as brooders and organisms with very short planktonic larval stages) may have a spatial distribution of the genetic diversity conforming to an isolation by distance (IBD) pattern. This pattern is expected when the dispersal potential of species is lower than their range of geographic distribution, leading to a strong relationship between genetic differentiation and geographic distance (e.g. Hoelzer et al. 2008). An extensive literature review by Thiel \& Haye (2006) underlined that rafting facilitates low to moderate levels of gene flow between populations of marine benthic brooders (see also Le Gac et al. 2004, Colgan et al. 2005, Hart et al. 2006). Taxa for which rafting had been inferred as a potential dispersal mechanism often displayed high levels of connectivity among both adjacent and distant populations and did not show an IBD pattern. Intermittent and frequent rafting allows high connectivity between localities, breaking the IBD pattern of genetic diversity that is otherwise expected. Thus, rafting may shape local population and metapopulation dynamics (see Thiel \& Haye 2006).

Some of the most common species in floating kelps are boring isopods from the genus Limnoria Leach that brood their offspring (Edgar 1987, Edgar \& Burton 2000, Thiel \& Vásquez 2000). Kelp-boring species of Limnoria excavate extensive burrows in the holdfasts and haptera of large kelps (Menzies 1957, Jones 1971, Edgar 1987, Thiel \& Vásquez 2000, Thiel 2003a). They feed on holdfast tissue that they rasp with their mandibles from within their burrows (Cragg et al. 1999). Present knowledge suggests that individual isopods reside for long time periods within the same burrow if undisturbed (Thiel 2003a). Most burrows harbor only 1 individual, but females may cohabit with males and with their offspring (Menzies 1957). Reproductive females care for their developing offspring within their burrows, and upon reaching subadult size, juveniles recruit directly into their natal holdfasts (Thiel 2003a). Extended parental care and local recruitment favor population persistence in floating substrata during extended rafting journeys (Thiel 2003b). These behaviors also make limnoriids very efficient colonizers of new habitats. For example, Nikula et al. (2010) inferred that the brooders L. stephenseni and Parawaldeckia kidderi colonized the subantarctic region by rafting dispersal on their kelp host Durvillaea antarctica. Similarly, Fraser et al. (2011) reported long-distance rafting dispersal (400-600 km) from subantarctic islands to the southern coast of New Zealand (NZ). Ten epifaunal invertebrate species, including Limnoria spp., were transported attached or inside the kelp $D$. antarctica.

The Chilean mainland coast extends over 37 degrees of latitude $(4100 \mathrm{~km})$ along the SE Pacific. Limnoriids occur along most of this extensive coastline, where they are abundant in floating algae (Hinojosa et al. 2007). To date, 2 species of Limnoria are reported for the Chilean coast. L. quadripunctata has a worldwide distribution and lives primarily in wood (Antezana 1968), but also occasionally occurs in algae (Cookson 1991), while L. chilensis inhabits kelp holdfasts (Menzies 1962). Even though only $L$. chilensis has been reported in kelp holdfasts along the Chilean coast, a suite of microsatellite loci only amplified on a subset of local populations of kelpdwelling Limnoria spp., suggesting that there might be greater diversity of Limnoria dwelling in kelps (Haye \& Marchant 2007). One goal of this study was to shed light on the number of kelp-dwelling species of Limnoria present along the coast of Chile.

The large abundances of floating macroalgae (mainly from the genera Macrocystis and Durvillaea) found along the Chilean coast (Macaya et al. 2005, Hinojosa et al. 2011) offer ample opportunity for rafting dispersal. The high dispersal potential of floating substrata along the Chilean coast suggests a high connectivity between distant locations. Conservative estimates have suggested that patches of Macrocystis can float for more than 2 wk (Macaya et al. 2005), and a recent study showed very high growth rates for algae floating at temperatures $<15^{\circ} \mathrm{C}$, indicating that under these conditions, kelp rafts may even stay afloat for several months (Rothäusler et al. 2009). During this time period, and considering typical current velocities of 10 to $20 \mathrm{~cm} \mathrm{~s}^{-1}$ in the surface waters of the Humboldt Current System (Marin \& Delgado 

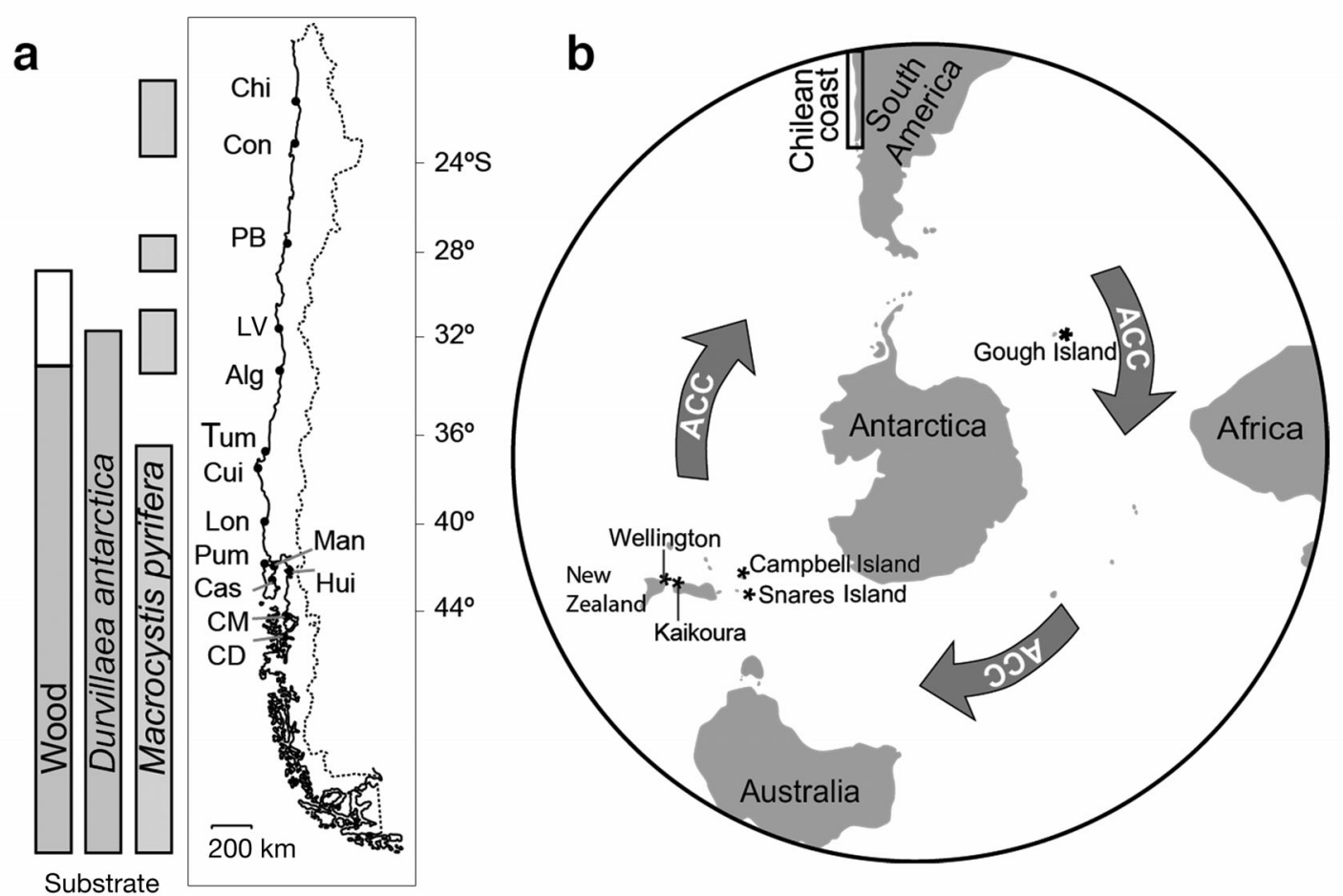

Fig. 1. (a) Chile, showing sampling locations and the distribution of the main rafting substrata. For wood, the grey area indicates abundant wood and many rivers while the white area corresponds to regions with less wood available and few rivers. Codes for sites as in Table 1. (b) Subantarctic region. The approximate position and direction of the Antarctic Circumpolar Current (ACC) are shown. Locations highlighted include the main study area, the Chilean coast (rectangle), and other sites for which limnoriids were included in the analyses (all marked with an asterisk). From Wellington, New Zealand, Limnoria spp. samples and sequences were obtained de novo. From Gough, Snares, and Campbell Islands, sequences were obtained from GenBank

2007), kelp rafts together with their long-term inhabitants may easily be transported over $100 \mathrm{~s}$ of $\mathrm{km}$ along the Chilean coast (Thiel 2003b).

Most previous studies have a posteriori suggested rafting as a means of dispersal when species with a low potential of autonomous dispersal display high levels of genetic connectivity between distant populations with no IBD (e.g. Waters \& Roy 2004). In the present study, we followed a different approach by predicting rafting effects a priori. For species of the genus Limnoria, which have direct development with high potential of passive dispersal, we hypothesized that recent and/or ongoing rafting-mediated gene flow leads to low genetic differentiation over large spatial scales and a lack of IBD.

\section{MATERIALS AND METHODS}

\section{Study region and sampling procedure}

Samples for this study were taken from 14 sites in Chile between Chipana in the north $\left(21^{\circ} \mathrm{S}\right)$ and the fjord region $\left(45^{\circ} \mathrm{S}\right)$ in the south (Fig. 1a). The study extended over a wide geographic range that crosses at least 1 biogeographic break situated by most recent authors around $30^{\circ} \mathrm{S}$ (Camus 2001) that has congruent phylogeographic breaks in populations of organisms with limited dispersal potential (e.g. Tellier et al. 2009, Sánchez et al. 2011). Furthermore, 6 individuals of Limnoria segnis were obtained from the Wellington area, NZ (Fig. 1b). We focused on holdfasts of Macrocystis pyrifera and Durvillaea antarctica because these algae are positively buoyant, float at the sea surface when detached, and have a wide distribution along the Chilean coast (Fig. 1a). Some species of Limnoria have been reported from both wood and kelp holdfasts (e.g. L. quadripunctata; Antezana 1968, Cookson 1991) and might have been dispersed by wooden ships. Consequently, in the northern fjord region (about $42^{\circ} \mathrm{S}$ ) where abundant driftwood can be found, we also obtained samples from wood.

Samples were taken from subtidal kelp beds in central $\left(30^{\circ}\right.$ to $\left.36^{\circ} \mathrm{S}\right)$ and northern Chile, while in southern Chile most samples came from kelp hold- 
Table 1. Limnoria spp. Collection sites and number of individuals of L. chilensis $(L C)$ and L. quadripunctata $(L q)$ collected along the coasts of Chile and of $L$. segnis ( $L s$ ) from Wellington, New Zealand (NZ). Substrata from which samples were obtained are indicated and numbers correspond to sample size analyzed

\begin{tabular}{|c|c|c|c|c|c|c|c|c|}
\hline \multirow{2}{*}{ Country } & \multirow{2}{*}{ Location } & \multirow{2}{*}{ Code } & \multirow{2}{*}{$\begin{array}{l}\text { Latitude } \\
\quad\left({ }^{\circ} \mathrm{S}\right)\end{array}$} & \multirow{2}{*}{$\begin{array}{l}\text { Tidal } \\
\text { zone }\end{array}$} & \multicolumn{3}{|c|}{ Substratum } & \multirow[t]{2}{*}{ Total } \\
\hline & & & & & Macrocystis pyrifera & Durvillaea antarctica & Wood & \\
\hline \multirow[t]{14}{*}{ Chile } & Chipana & Chi & 21.33 & Subtidal & $23 L q$ & & & 23 \\
\hline & Caleta Constitución & Con & 23.42 & Subtidal & $14 \mathrm{Lq}$ & & & 14 \\
\hline & Playa Blanca & $\mathrm{PB}$ & 28.19 & Subtidal & $23 L q$ & & & 23 \\
\hline & Los Vilos (south) & $\mathrm{LV}$ & 32.02 & Subtidal & $22 L q$ & & & 22 \\
\hline & Algarrobo & Alg & 33.36 & Subtidal & $27 \mathrm{Lq}$ & & & 27 \\
\hline & Tumbes & Tum & 36.64 & Intertidal & $5 L q$ & $2 L C$ & & 7 \\
\hline & Cuidico & Cui & 37.37 & Intertidal & $6 L q$ & $1 L C$ & & 7 \\
\hline & Punta Loncoyén & Lon & 39.82 & Intertidal & $18 \mathrm{Lq}$ & $8 L C$ & & 26 \\
\hline & Pumillahue & Pum & 41.95 & Intertidal & $15 L C$ & $2 L C$ & & 17 \\
\hline & Huinay & Hui & 42.39 & Subtidal & & & $41 \mathrm{Lq}$ & 41 \\
\hline & Castro & Cas & 42.48 & Intertidal & & & $8 L q$ & 8 \\
\hline & Manao & Man & 41.90 & Intertidal & & & $9 L q$ & 9 \\
\hline & Moraleda Channel & $\mathrm{CM}$ & 44.87 & Floating & & $16 L C$ & & 16 \\
\hline & Darwin Channel & $\mathrm{CD}$ & 45.44 & Intertidal & & $7 L C$ & & 7 \\
\hline NZ & Wellington & $\mathrm{NZ}$ & 41.30 & Subtidal & $6 \mathrm{Ls}$ & & & 6 \\
\hline Total & & & & & 159 & 36 & 58 & 253 \\
\hline
\end{tabular}

fasts collected in the low intertidal zone (Table 1). In accordance with substratum availability (Fig. 1a), in northern and central Chile we collected individuals of Limnoria quadripunctata from Macrocystis pyrifera. In the southern part of the study area, from 36 to $42^{\circ} \mathrm{S}$, individuals of both species were collected: $L$. chilensis from Durvillaea antarctica, L. quadripunctata from $M$. pyrifera (1 southern population of $M$. pyrifera contained L. chilensis) and wood (Table 1). To collect individuals, holdfasts were carefully detached from the benthic substratum and placed in individual plastic bags. At each site, we collected isopods from several holdfasts (at least 10 holdfasts). On the shore, holdfasts were dissected to expose and collect the isopods which were immediately placed in $95 \%$ ethanol. Similarly, wood was collected from the intertidal and subtidal zone and dissected for isopods. Whenever possible, we collected only adult isopods, because these have likely migrated between holdfasts (see Miranda \& Thiel 2008), thereby reducing the risk of sampling siblings. After $24 \mathrm{~h}$, the ethanol from all vials was exchanged with fresh $95 \%$ ethanol. Collected individuals were maintained at ambient temperatures during fieldwork (for a maximum of $20 \mathrm{~d}$ ), and subsequently returned to the lab where they were stored at $-20^{\circ} \mathrm{C}$ after changing the preserving alcohol.

Individuals collected from wood were morphologically identified as Limnoria quadripunctata, and those from Macrocystis pyrifera as L. cf. quadripunctata, because even if highly similar to L. quadripunc- tata from wood, the ones from M. pyrifera lacked a rasp on the left mandible (L. Cookson pers. comm.). All individuals collected from Durvillaea antarctica were identified as $L$. chilensis. This latter species was also found in M. pyrifera in the locality of Pumillahue $\left(41^{\circ} \mathrm{S}\right)$. Summarizing, for the coast of Chile, $79.4 \%$ of the individuals analyzed were L. quadripunctata, and $20.6 \%$ were $L$. chilensis.

\section{Data collection}

Whole individuals were homogenized (after the removal of embryos in the case of ovigerous females) and their genomic DNA was extracted using a QIAamp DNA mini kit (Qiagen) following the instructions of the manufacturer. Polymerase chain reaction (PCR) was used to amplify a portion of the mitochondrial DNA cytochrome oxidase I (COI) gene using the universal primers $\mathrm{HCO}$ and LCO of Folmer et al. (1994). Sequences of the more conserved nuclear 28S rDNA (28S) gene were obtained for 13 individuals using the primers 28SniphF1 and 28SniphR1 (Lefébure et al. 2006). We used DNA from 1 individual of Limnoria segnis from NZ, and 6 individuals each for both $L$. chilensis and $L$. quadripunctata from the Chilean coast.

The PCR mix consisted of $\sim 20 \mathrm{ng}$ of DNA, $1 \times$ PCR buffer, $2 \mathrm{mM} \mathrm{MgCl}_{2}$ for $\mathrm{COI}$ and $1 \mathrm{mM}$ for $28 \mathrm{~S}$, $0.4 \mu \mathrm{M}$ of each primer, $0.22 \mathrm{mM}$ of each dNTP, $1.5 \mathrm{U}$ of Taq polymerase, and $1.5 \mathrm{mg} \mathrm{ml}^{-1}$ bovine serum 
albumin. Cycling conditions consisted of an initial denaturing at $94^{\circ} \mathrm{C}$ for $10 \mathrm{~min}$ followed by 35 cycles of $1 \mathrm{~min}$ denaturing at $94^{\circ} \mathrm{C}, 1 \mathrm{~min}$ annealing at $51^{\circ} \mathrm{C}$ for COI and $57^{\circ} \mathrm{C}$ for $28 \mathrm{~S}$, and a 2 min extension at $72^{\circ} \mathrm{C}$. Purification of $45 \mu \mathrm{l}$ of the amplicon was achieved by adding $28.8 \mu \mathrm{l}$ of shrimp alkaline phosphatase and $7.2 \mu \mathrm{l}$ of Exonuclease I and incubating for $15 \mathrm{~min}$ at $37^{\circ} \mathrm{C}$ and $15 \mathrm{~min}$ at $80^{\circ} \mathrm{C}$. Subsequently, purified amplicons were concentrated through evaporation at $50^{\circ} \mathrm{C}$ for $4 \mathrm{~h}$. Sequencing was performed in both directions with an ABI 3730XL capillary automated sequencer. The software GENEIOUS 5.5.4 (Biomatters; www.geneious.com) was used to obtain a unique sequence for each individual and to perform alignment. The alignment was verified through translation into amino acid sequences that were generated using the invertebrate mitochondrial genetic code in GENEIOUS. The $28 \mathrm{~S}$ gene sequences were aligned in CLUSTAL-W (Thompson et al. 1994). Final aligned sequences for both genes were truncated at each extreme to produce equal length sequences.

It is worth noting that COI sequences obtained from 90 of the 343 Limnoria specimens did not correspond to Limnoria spp. sequences and were not used for the analyses. The discarded sequences (GenBank accession numbers FJ541266-FJ541275, FJ541277, FJ541278, FJ541280, FJ541282, and FJ541283) were extremely divergent from the Limnoria spp. COI sequences (up to $66 \%$ ) and did not match malacostracan species in GenBank. Instead, they matched DNA of gut contents found in the amphipod Eurythenes gryllus (GenBank accession number AY830420) and most likely represent sequences of gut content or epibionts of Limnoria spp. Care must be taken when using universal primers that will likely amplify genes of other organisms living in or on the target species.

\section{Data analysis}

COI sequences obtained for Limnoria chilensis and $L$. quadripunctata from the Chilean coast, and for $L$. segnis from NZ were analyzed together with sequences of Limnoria spp. obtained from GenBank. The included sequences were L. segnis from Kaikoura, NZ, L. chilensis from Snares Island (south of NZ), Gough Island (south Atlantic Ocean), and Chile $\left(36^{\circ} \mathrm{S}_{\text {; Fraser }}\right.$ et al. 2011, GenBank accession numbers HQ161076, HQ161071, HQ161075, and HQ161073, respectively), and L. stephenseni from Campbell Island south of NZ (Nikula et al. 2010, GenBank accession number
FJ608919) (Fig 1b). Sequences from 5 isopods and 1 amphipod species were used as outgroup taxa for COI analyses (Table S1 in the Supplement at www.intres.com/articles/suppl/m455p111_supp.pdf). The 28S sequences obtained from individuals of $L$. chilensis, $L$. quadripunctata, and $L$. segnis were analyzed using 14 amphipod sequences as outgroup taxa (Table S2 in the Supplement). No isopods could be used as an outgroup because the sequence portion available for $28 \mathrm{~S}$ aligned only partially to those of Limnoria spp. Their use would have considerably reduced the number of nucleotides for analyses.

COI data were analyzed at the nucleotide and amino acid levels, the latter to account for saturation at the nucleotide level. Maximum likelihood analyses (MLA) were conducted with PAUP* $4.0 \mathrm{~b} 10$ (Swofford 2002) and Bayesian analyses (BA) with MRBAYES 3.1.2 (Ronquist \& Huelsenbeck 2003). jModelTest 0.1.1 (Posada 2008) was used to select the model of nucleotidic substitution for each gene that was applied to MLA and BA. For BA of amino acid data, MRBAYES was set to estimate the best fixedrate model during the analysis. For MLA, support for the nodes was obtained from 10000 bootstrap replications. BA were performed using 5000000 iterations and sampling every 10 generations, ensuring that the average standard deviation of split frequencies was $<0.001$. The first $25 \%$ of the saved trees were discarded as burn-in.

For intra-specific analyses of Chilean specimens of Limnoria chilensis and L. quadripunctata, medianjoining haplotype networks for COI sequences were built with NETWORK 4.5 (Bandelt et al. 1999). Unresolved loops were analyzed with the coalescent criteria of Crandall \& Templeton (1993). ARLEQUIN 3.11 (Excoffier et al. 2005) was used to calculate population pairwise genetic differentiation through the haplotypic fixation index $\Phi_{\mathrm{ST}}$ (significance was determined with 1000 permutations), and to perform Mantel tests between the genetic (linearized $\Phi_{\mathrm{ST}}$ ) and geographic $(\mathrm{km})$ distance in order to test for IBD. DnaSP 5.10.00 (Librado \& Rozas 2009) was used to estimate diversity indices. In order to test for a sudden population expansion (Rogers 1995), Tajima's $D$ test and Mismatch frequency distribution analyses (Rogers \& Harpending 1992) were performed in ARLEQUIN. The validity of the fit to the sudden expansion model was tested using parametric bootstrap analysis. The sum of squared deviations between the observed and expected distribution of pairwise differences was used as the test statistic. The probability value (p) represents the probability that the model fits the observed data. Graphic repre- 
sentation of the frequency distribution of pairwise differences among haplotypes was obtained from DnaSP. If the mismatch distribution fit a sudden expansion model, time since the most recent expansion was obtained from $\tau$ ( $\tau=2 u t, t=$ time since expansion in number of generations, and $u=$ mutation rate per generation, Rogers 1995). The mutation rates used were those proposed by Knowlton \& Weigt (1998: $1.4 \times 10^{-8}$ ) for snapping shrimp (Caridea), based on the rise of the Isthmus of Panama, and Henzler (2006: $\left.4.8 \times 10^{-8}\right)$ for gammaridean amphipods (Peracarida) of the northern hemisphere, considering the opening of the Bering Strait. The latter is a conservative estimate based on a relatively fast mutation rate. However, both used rates are actually estimates of substitution rates, i.e. mutations that were fixed in each lineage. Substitution rates are much lower than mutation rates mainly because natural selection will remove a large proportion of spontaneous deleterious mutations (Ho et al. 2011).

\section{RESULTS}

\section{Phylogenetic analyses}

Partial sequences of the COI gene of 539 base pairs (bp) were obtained for a total of 253 individuals of Limnoria (Table 1): 51 L. chilensis, 196 L. quadripunctata, both from Chile, and $6 \mathrm{~L}$. segnis from NZ. The MLA and BA of COI nucleotide and amino acid data (Table S3 in the Supplement) resulted in similar tree topologies (Fig. 2b), although branch support was higher for the topology derived from the amino acid data. Phylogenetic analyses of a $777 \mathrm{bp}$ sequence of 28S rDNA (Table S4 in the Supplement) of 1 individual of $L$. segnis from NZ, 6 from $L$. quadripunctata, and 6 from L. chilensis, are highly consistent with the COI gene tree (Fig. 2c). The results of both data sets indicate that Chilean $L$. quadripunctata are monophyletic and are a sister clade of the other Limnoria species analyzed. Se- a

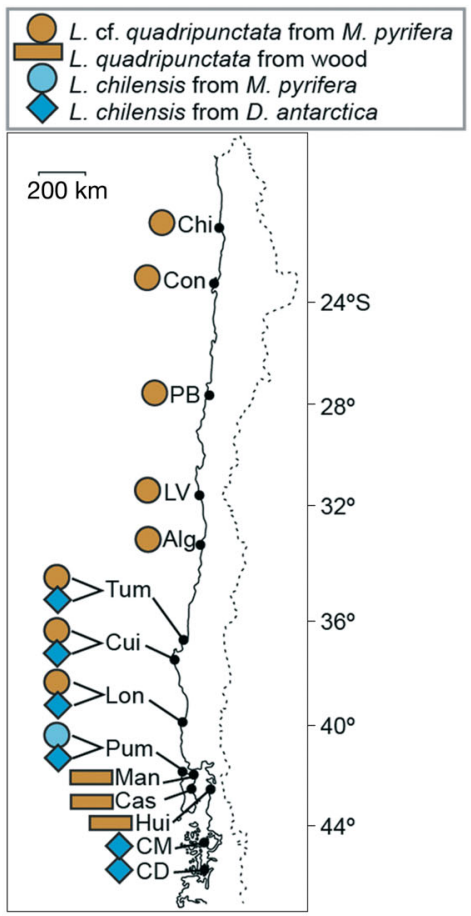

b

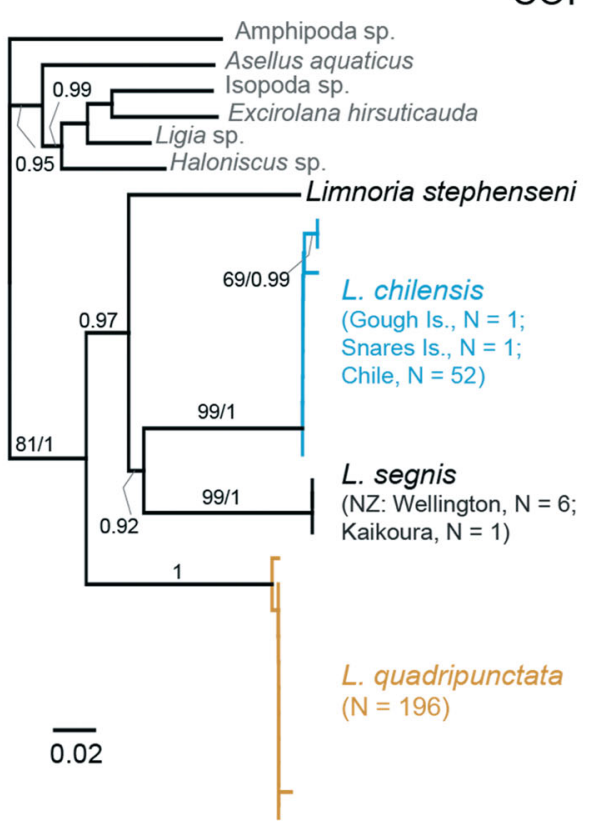

C $28 \mathrm{~S}$

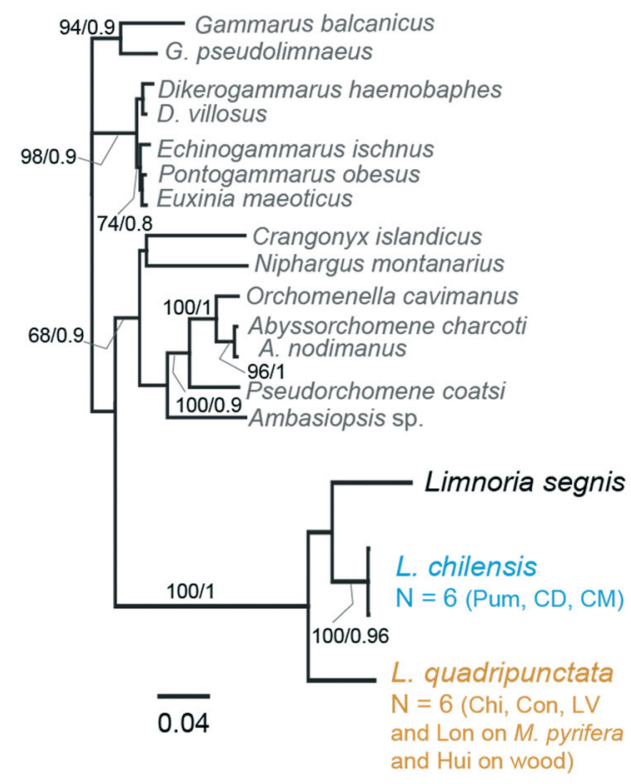

Fig. 2. Limnoria spp. (a) Geographic distribution of the 2 species sampled in Chile, L. quadripunctata and L. chilensis, represented with different colors on the map. Codes for sites are given in Table 1. Shapes symbolize the substratum where samples were collected (Macrocystis pyrifera, Durvillaea antarctica, and wood). (b) Rooted maximum likelihood (ML) phylogram of the 18 cytochrome oxidase I haplotypes found in the 247 Chilean individuals analyzed including 2 haplotypes of $L$. segnis and other sequences of Limnoria spp. obtained by Nikula et al. (2010) and Fraser et al. (2011) as well as of other peracarids as outgroup taxa from GenBank. N: number of individuals sampled of each clade. The 2 numbers along branches correspond to bootstrap values $>65 \%$ (10000 replicates) and Bayesian posterior probabilities $>0.8$, respectively. For a few nodes, only the posterior probability is shown. (c) ML phylogram of three 28S sequences found among the 13 specimens analyzed, 12 from the coast of Chile and 1 from New Zealand (NZ), and of amphipod sequences used as outgroup. In (b) and (c), the scale bar represents the number of substitutions per site 
quences of $L$. chilensis obtained from distant localities (coast of Chile and subantarctic islands) form a well-defined monophyletic group.

\section{Geographic diversity of Chilean Limnoria spp.}

In Chile, Limnoria quadripunctata is widely distributed from Chipana $\left(21^{\circ} \mathrm{S}\right)$ to Castro $\left(42^{\circ} \mathrm{S}\right.$; Fig. 2a). Individuals were collected from Macrocystis pyrifera in northern localities and from wood in some southern locations. L. chilensis mostly inhabited Durvillaea antarctica and are therefore restricted to the south of Chile (Fig. 2a). Only in Pumillahue, $L$. chilensis was found both in $M$. pyrifera and $D$. antarctica. L. chilensis and L. quadripunctata are sympatric kelp dwellers in Tumbes, Cuidico, and Loncoyén (between 36 and $39^{\circ} \mathrm{S}$ ). Throughout their sympatric geographic range, the 2 species use different substrata ( $L$. chilensis dwells in $D$. antarctica and L. quadripunctata in M. pyrifera; Fig. 2a).

Intra-species analyses of the COI data along the Chilean coast were performed for both species (Table 2). Haplotype diversity was similar between species, while nucleotide diversity was lower in Limnoria quadripunctata $(0.0015)$ than in L. chilensis (0.0040). Individuals of $L$. quadripunctata collected from wood had the greatest haplotypic and nucleotidic diversity (Table 2, Fig. 3).

Both haplotype networks showed a dominant haplotype shared among most sampled locations (Fig. 3). The haplotype network of Limnoria quadripunctata has a star-like shape, suggesting that all samples conform to 1 population that has experienced a rapid expansion. The most common and putative ancestral haplotype is present at almost all localities, with the exception of Huinay (Hui), where only haplotypes unique to wood were found (Fig. 3a). For L. chilensis, only Cuidico and Darwin Channel lack the most common haplotype (Fig. 3b). Haplotypes from Darwin Channel, the southernmost location sampled, differ in 2 and 3 mutational steps from the most common haplotype.

Population pairwise $\Phi_{\mathrm{ST}}$ values showed evidence of very low genetic differentiation between distant populations for Limnoria quadripunctata, such as between Punta Loncoyén and Chipana to the north, which are separated by ca. $2000 \mathrm{~km}$. In contrast, Algarrobo and the wood samples Manao, Huinay, and Castro were significantly differentiated from most other populations (Table 3), consistent with the presence of unique haplotypes at these localities (Fig. 3a).
Table 2. Limnoria chilensis and L. quadripunctata. Intraspecies cytochrome oxidase I genetic diversity indices along the coast of Chile. Codes for sites are given in Table 1. N: number of individuals, $S$ : number of segregating (variable) nucleotide positions, $H$ : number of haplotypes, $h$ : haplotype diversity, $\pi$ : nucleotide diversity, $k$ : average number of nucleotide differences between sequences

\begin{tabular}{|lrrcccc|}
\hline Site & N & $S$ & $H$ & $h$ & $\pi$ & $k$ \\
\hline L. chilensis & & & & & & \\
Tum & 2 & 0 & 1 & 0.000 & 0.0000 & 0.000 \\
Cui & 1 & 0 & 1 & - & - & - \\
Lon & 8 & 3 & 2 & 0.571 & 0.0032 & 1.714 \\
Pum $M^{\text {a }}$ & 15 & 3 & 2 & 0.343 & 0.0019 & 1.029 \\
Pum $D^{\text {a }}$ & 2 & 0 & 1 & 0.000 & 0.0000 & 0.000 \\
CM & 16 & 5 & 3 & 0.542 & 0.0036 & 1.958 \\
CD & 7 & 1 & 2 & 0.476 & 0.0008 & 0.476 \\
Total & 51 & 7 & 7 & 0.704 & 0.0040 & 2.155 \\
L. quadripunctata & & & & & & \\
Chi & 23 & 0 & 1 & 0.000 & 0.0000 & 0.000 \\
Con & 14 & 1 & 2 & 0.143 & 0.0003 & 0.143 \\
PB & 23 & 0 & 1 & 0.000 & 0.0000 & 0.000 \\
LV & 22 & 1 & 2 & 0.312 & 0.0006 & 0.312 \\
Alg & 27 & 1 & 2 & 0.074 & 0.0001 & 0.074 \\
Tum & 5 & 0 & 1 & 0.000 & 0.0000 & 0.000 \\
Cui & 6 & 1 & 2 & 0.533 & 0.0009 & 0.533 \\
Lon & 18 & 1 & 2 & 0.111 & 0.0002 & 0.111 \\
Man & 9 & 3 & 4 & 0.694 & 0.0019 & 1.000 \\
Hui & 41 & 5 & 5 & 0.582 & 0.0021 & 1.156 \\
Cas & 8 & 2 & 3 & 0.714 & 0.0016 & 0.857 \\
Total & 196 & 10 & 11 & 0.640 & 0.0015 & 0.807 \\
a Substratum, M: Macrocystis & pyrifera and D: Durvillaea \\
antarctica & & & & & & \\
\hline
\end{tabular}

Most of the population pairwise $\Phi_{\mathrm{ST}}$ values of Limnoria chilensis showed low genetic differentiation among populations (Table 4), even for the most distant populations of Tumbes and the Darwin Channel $(\sim 1000 \mathrm{~km})$. However, the fjord region is significantly differentiated from Loncoyén and Pumillahue (in the latter, only for individuals collected from Macrocystis pyrifera). In addition, differentiation is high between both channels (Darwin and Moraleda; $\Phi_{\mathrm{ST}}=0.483$, $\mathrm{p}<0.05$ ), and between Cuidico and other localities (values are non-significant). This is likely due to the fact that we were only able to collect 1 individual of L. chilensis in Cuidico. Correlation analyses of genetic and geographic distance matrices through a Mantel test indicate that there is no IBD pattern for either of the 2 species ( $L$. chilensis, $\mathrm{p}=0.248$; L. quadripunctata, $\mathrm{p}=0.291$ ).

The mismatch frequency distributions of species did not deviate significantly from the null hypothesis of a sudden population expansion model (Fig. 4), with $\tau$ values of 1.236 and 1.355 for Limnoria chilensis and L. quadripunctata, respectively. Only the mismatch frequency distribution of $L$. quadripunctata is clearly unimodal (Fig. 4), consistent with the star-like 
a

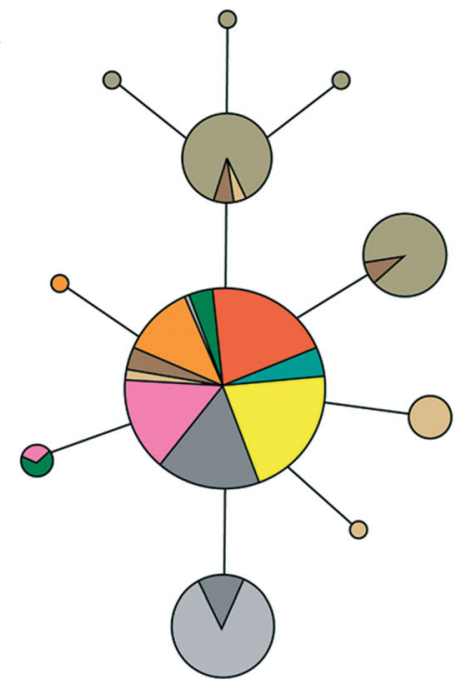

b

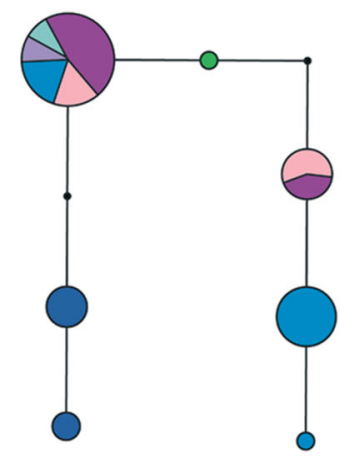

C

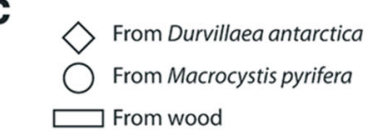

From wood

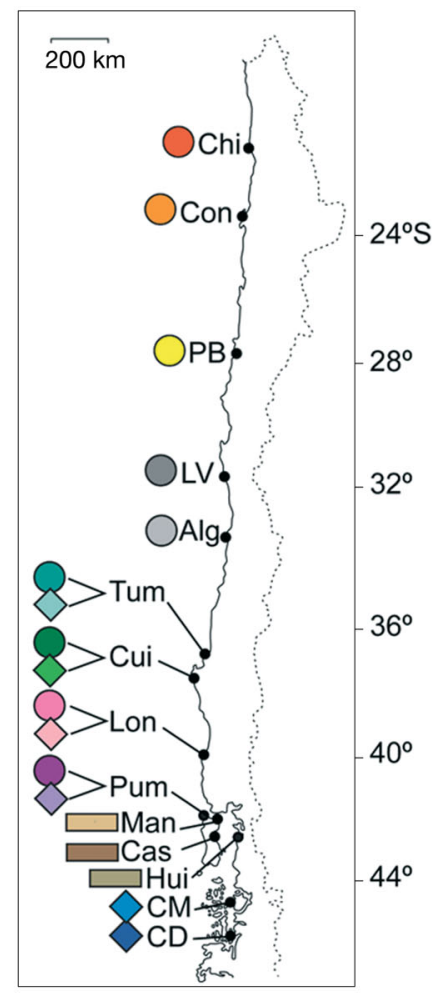

Fig. 3. Limnoria quadripunctata and L. chilensis. (a,b) Median-joining cytochrome oxidase I haplotype networks of haplotypes found along the coast of Chile. Circles represent each haplotype, and their size is proportional to their frequency. The smallest colored circles represent haplotypes found in 1 individual. Lines connecting haplotypes represent a mutational step; small black dots along the lines indicate hypothetical or undetected haplotypes. The circles representing haplotypes are subdivided when the haplotype was found in more than 1 locality. (c) Each locality is represented by a different color in the map. Codes for sites are given in Table 1. Shapes symbolize the substratum where samples were collected (Macrocystis pyrifera, Durvillaea antarctica, and wood) shape of the haplotype network. Tajima's $D$ values were -0.2144 and 0.5528 ( $\mathrm{p}>0.1$ ) for L. quadripunctata and L. chilensis, respectively, indicating that the COI gene is neutral to natural selection and is in mutationdrift equilibrium. Sudden population expansion can be inferred for $L$. quadripunctata but not for $L$. chilensis, which seems to have been under a stable effective population size for the last hundreds of thousands of years. Using the mutation rates proposed by Knowlton \& Weigt (1998) and Henzler (2006), the estimated time for the latest population expansion for L. quadripunctata was between 90000 and 26000 yr ago.

\section{DISCUSSION}

The 2 species of Limnoria detected along the coast of Chile, L. chilensis and L. quadripunctata, have the expected genetic signatures of relatively recent or ongoing rafting: there is low genetic differentiation and a lack of strong geographic structure of the genetic diversity at a macrogeographic scale.

When Limnoria chilensis and $L$. quadripunctata are sympatric along the Chilean coast, they bore into different substrata. Host use seems to be an important phylogenetic driver in Limnoria spp. The phylogenetic relationships among the Limnoria spp.

Table 3. Limnoria quadripunctata. Cytochrome oxidase I population pairwise $\Phi_{\mathrm{ST}}$ values among the 11 surveyed populations. Significant pairwise values $(\mathrm{p}<0.05)$ are marked in bold. Codes for sites are given in Table 1

\begin{tabular}{|lcccccccccc}
\hline & Con & PB & LV & Alg & Tum & Cui & Lon & Man & Hui & Cas \\
\hline Chi & \multirow{2}{*}{0.037} & 0.000 & $\mathbf{0 . 1 4 7}$ & $\mathbf{0 . 9 5 8}$ & 0.000 & $\mathbf{0 . 5 0 5}$ & 0.014 & $\mathbf{0 . 7 1 1}$ & $\mathbf{0 . 6 5 2}$ & $\mathbf{0 . 5 0 1}$ \\
Con & & 0.037 & 0.042 & $\mathbf{0 . 8 9 8}$ & -0.098 & 0.199 & -0.031 & $\mathbf{0 . 5 2 3}$ & $\mathbf{0 . 5 7 0}$ & $\mathbf{0 . 2 6 4}$ \\
PB & & & $\mathbf{0 . 1 4 7}$ & $\mathbf{0 . 9 5 8}$ & 0.000 & $\mathbf{0 . 5 0 5}$ & 0.014 & $\mathbf{0 . 7 1 1}$ & $\mathbf{0 . 6 5 2}$ & $\mathbf{0 . 5 0 1}$ \\
LV & & & & $\mathbf{0 . 7 7 0}$ & 0.004 & 0.115 & 0.063 & $\mathbf{0 . 4 4 0}$ & $\mathbf{0 . 5 3 0}$ & $\mathbf{0 . 1 8 6}$ \\
Alg & & & & & $\mathbf{0 . 9 3 5}$ & $\mathbf{0 . 8 2 6}$ & $\mathbf{0 . 9 0 8}$ & $\mathbf{0 . 7 4 1}$ & $\mathbf{0 . 6 3 7}$ & $\mathbf{0 . 7 4 6}$ \\
Tum & & & & & & 0.161 & -0.103 & $\mathbf{0 . 4 6 2}$ & $\mathbf{0 . 5 5 4}$ & 0.200 \\
Cui & & & & & & 0.207 & $\mathbf{0 . 2 6 9}$ & $\mathbf{0 . 4 3 2}$ & 0.057 \\
Lon & & & & & & & & $\mathbf{0 . 5 7 6}$ & $\mathbf{0 . 5 9 4}$ & $\mathbf{0 . 3 2 3}$ \\
Man & & & & & & & & & $\mathbf{0 . 3 4 2}$ & $\mathbf{0 . 1 8 2}$ \\
Hui & & & & & & & & & & \\
\hline
\end{tabular}


Table 4. Limnoria chilensis. Cytochrome oxidase I population pairwise $\Phi_{\mathrm{ST}}$ values among the 6 surveyed populations. In Pum, samples were obtained both from Macrocystis pyrifera $(M)$ and Durvillaea antarctica $(D)$. Significant pairwise values $(\mathrm{p}<0.05)$ are marked in bold. Codes for sites are given in Table 1

\begin{tabular}{|lrrrrrr|}
\hline & Cui $D$ & Lon $D$ & Pum $M$ & Pum $D$ & CM & CD \\
\hline Tum & 1.000 & 0.158 & -0.188 & 0.000 & 0.364 & 0.620 \\
Cui & & 0.429 & 0.657 & 1.000 & 0.458 & 0.524 \\
Lon & & & 0.106 & 0.158 & $\mathbf{0 . 3 4 3}$ & $\mathbf{0 . 4 7 4}$ \\
Pum $M$ & & & & -0.188 & $\mathbf{0 . 4 0 8}$ & $\mathbf{0 . 6 0 9}$ \\
Pum $D$ & & & & & 0.364 & 0.620 \\
CM & & & & & $\mathbf{0 . 4 8 3}$ \\
\hline
\end{tabular}

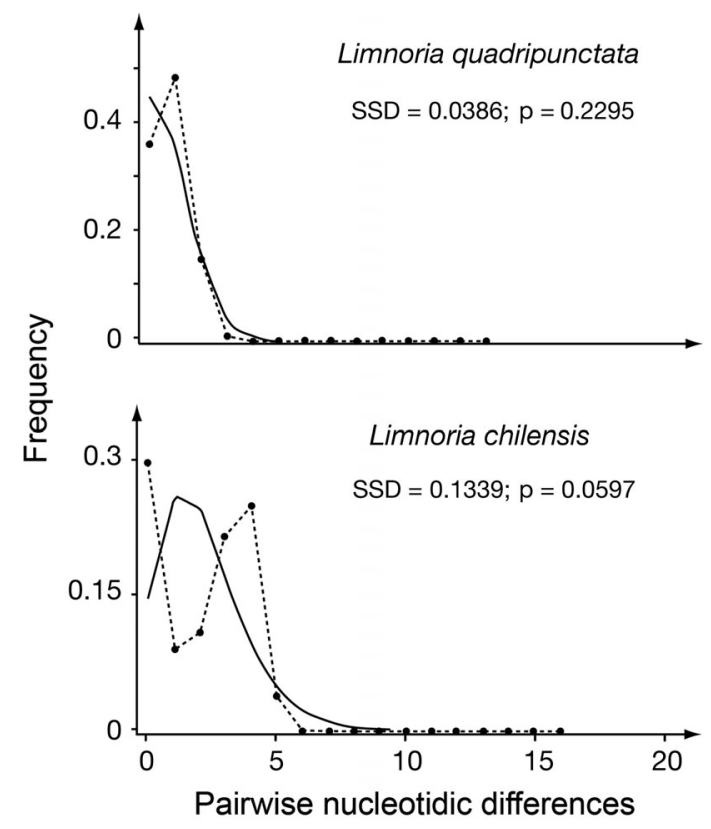

Fig. 4. Limnoria quadripunctata and L. chilensis. Cytochrome oxidase I mismatch distributions of pairwise sequences found on the coast of Chile. The continuous line represents the expected curve under a sudden expansion model while the dashed line corresponds to the observed data. SSD: sum of squared deviations between observed and expected distributions

included in the study seem to be strongly associated with their preferred substrata. The mitochondrial COI and nuclear $28 \mathrm{~S}$ gene trees largely agree on the placement of Limnoria spp., suggesting that $L$. quadripunctata is sister species of the species dwelling in Durvillaea antarctica at mid and high latitudes of the southern hemisphere, which form a monophyletic group.
Limnoria quadripunctata from Chile was found in the kelp Macrocystis pyrifera and in wood, forming a monophyletic clade according to both the molecular markers. This is the first report of $L$. quadripunctata boring in kelp holdfasts along the coast of Chile. Presumably both speciation and phenotypic plasticity play a role in limnoriid evolution. The one consistent morphological difference (rasp on mandible) between individuals inhabiting M. pyrifera and wood may be indicating adaptive phenotypic plasticity related to different ecological environments (e.g. Thibert-Plante \& Hendry 2011), i.e. host use being a selective factor.

For both species, rafting-mediated connectivity explains their ample range of distribution, as also suggested for other species from the genus Limnoria (Hill \& Kofoid 1927, Johnson 1935, Svavarsson 1982). L. quadripunctata has a worldwide distribution, and in Chile it was found throughout almost the entire geographic extension studied $(>2350 \mathrm{~km}$ from Chipana, $21^{\circ} \mathrm{S}$, to Castro, $\left.42^{\circ} \mathrm{S}\right)$. L. chilensis also has a wide geographic distribution with individuals found in southern Chile from Tumbes $\left(36^{\circ} \mathrm{S}\right)$ to Darwin Channel $\left(45^{\circ} \mathrm{S}\right)$ and in the subantarctic Snares and Gough Islands. There is high abundance of Durvillaea rafts in the path of the West Wind Drift (a strong west to east current), suggesting that dispersal events in the subantarctic region are common (Smith 2002, Waters \& Roy 2004, Donald et al. 2005, Fraser et al. 2009, Nikula et al. 2010) and may maintain connectivity of $L$. chilensis.

Low levels of genetic differentiation and lack of IBD for limnoriid species along the Chilean coast may be consequence of past and/or ongoing rafting dispersal supporting our a priori hypothesis. Even though sample size may be biasing the intra-species analyses (mainly because of unequal sample size per site), both the limnoriid species studied have a common haplotype that is shared among most sampled localities. Distant local populations (i.e. $1000 \mathrm{~km}$ for Limnoria chilensis and $>2000 \mathrm{~km}$ for L. quadripunctata) have low levels of genetic differentiation. Instead of an IBD pattern, as expected for species with limited dispersal potential, along the Chilean coast both Limnoria species show a genetic structure that reflects occasional and stochastic incorporation of migrants of diverse geographic origins into local populations (e.g. Buchanan \& Zuccarello in press). Past and/or current gene flow between local populations of limnoriids is consistent with the high abundance of floating algae along the coast of Chile (Macaya et al. 2005, Hinojosa et al. 2011), many of which harbor limnoriids (e.g. Hinojosa et al. 2007), 
and the high potential of successful colonization of limnoriids (Thiel 2003a,b, Miranda \& Thiel 2008). Using additional (variable nuclear) markers should allow us to determine whether the detected shared COI haplotypes represent ancestral polymorphisms or current gene flow, or a mixture of both (Marko \& Hart 2011). If they correspond mainly to ancestral polymorphisms, ongoing gene flow would be more limited than expected given the abundance of floating algae and the low COI differentiation between localities. Regardless of whether gene flow is still ongoing, our data suggest that gene flow has occurred until relatively recently.

The nucleotide mismatch frequency distribution analyses of the 2 species along the coast of Chile were not coincident. Only Limnoria quadripunctata shows evidence of a sudden population expansion event, which was estimated to have occurred between 90000 and 26000 yr ago. These estimations are likely to be overestimated by 10 -fold since the rates we used approximate substitution rates rather than mutation rates (Ho et al. 2005). The precise timing of the population expansion event is uncertain; however, it is likely that it occurred some time during the Late Pleistocene period ( 175000 to $10000 \mathrm{yr}$ ago) or even more recently. The population expansion in L. quadripunctata may have been enhanced by glaciation cycles during the Pleistocene period as inferred for the spiny lobster Palinurus elephas (Palero et al. 2008). Also, oceanographic events such as the intensification of the northward flowing Humboldt Current during the Last Glacial Maximum (Feldberg \& Mix 2002) could have facilitated population expansion of $L$. quadripunctata along the coast of Chile via algal/wood rafting. It is also possible that during the expansion period additional introductions of L. quadripunctata might have occurred, which (if derived from similar source populations) could lead to the detected pattern. Furthermore, there may be very recent or ongoing dispersal of $L$. quadripunctata by wooden ships (in addition to floating $M$. pyrifera) along the Chilean coast (see e.g. Antezana 1968) and possibly across the Southern Ocean, a scenario previously discussed for $L$. chilensis rafting on D. antarctica. Future studies should examine the global phylogeography of L. quadripunctata and other putative cosmopolitan species of Limnoria spp. using a battery of DNA markers.

The average nucleotide diversity of Limnoria chilensis was 2.66 times greater than for L. quadripunctata. Even though comparing nucleotide diversity between taxa may be arguable, there are some biological factors that may be leading to this differ- ence, acting separately or together, such as a comparably higher effect of genetic drift in L. quadripunctata than in L. chilensis along the coast of Chile. These may be due to events such as bottlenecks and/or founder effects, and a relatively smaller effective population size of $L$. quadripunctata. A lower diversity could be a consequence of a more recent colonization of the Chilean coast by L. quadripunctata than $L$. chilensis, not giving enough time for the accumulation of nucleotide diversity in L. quadripunctata. Along the Chilean coast the greatest haplotype diversity of L. quadripunctata was found south of $36^{\circ} \mathrm{S}$ (southern Chile). Kelp forests along the northern coast of Chile experience frequent local extinction due to El Niño events (Castilla \& Camus 1992, Camus et al. 1994, Vega et al. 2005), and local limnoriid populations may temporarily go extinct; recurrent bottlenecks and colonization events would lead to genetic diversity loss. Alternatively, or in combination with the above scenario, the genetic diversity pattern of $L$. quadripunctata can be skewed because of a more recent colonization of the northern coast of Chile where the species has not yet had enough time to accumulate the same degree of genetic diversity as in the south, or because founding populations were small and subject to strong genetic drift. Another consideration is that in the south $L$. quadripunctata came from 2 different substrata, Macrocystis pyrifera and wood, which could lead to the overall pattern of lower genetic diversity in the north where only algal-dwelling limnoriids were collected. Phylogenetic and phylogeographic analyses of both species, considering their range of distribution, are necessary to determine the main factors that lead to their difference in genetic diversity along the coast of Chile.

Acknowledgements. We thank I. Hinojosa, L. Miranda, and E. Macaya for help with sample collection. We especially thank R. Vera for help in optimizing the PCR reactions in Limnoria spp. We thank M. Schotte for initial help with the identification of Limnoria from Chile, and especially L. Cookson for confirming species identifications and noticing morphological divergence between $L$. quadripunctata from wood and kelp. Thoughtful comments and suggestions by M. Rivadeneira, B. Broitman, I. Kornfield, C. Fraser, and 3 anonymous reviewers are greatly appreciated. FONDECYT 1051076 fully supported this research.

\section{LITERATURE CITED}

Antezana T (1968) Limnoria (Limnoria) quadripunctata Holthuis (Crustacea, Isopoda), nuevo exponente de la fauna del Pacífico sur-oriental. Rev Biol Mar Oceanogr 13:293-301 
Bandelt HJ, Forster P, Röhl A (1999) Median-joining networks for inferring intraspecific phylogenies. Mol Biol Evol 16:37-48

Buchanan J, Zuccarello GC (in press) Decoupling of short and long distance dispersal pathways in the endemic New Zealand seaweed Carpophyllum maschalocarpum (Phaeophyceae, Fucales). J Phycol doi:10:111/j.1529-8817. 2012.01167.x

> Camus P (2001) Biogeografía marina de Chile continental. Rev Chil Hist Nat 74:587-617

Camus PA, Vásquez JA, González EO, Galáz LE (1994) Fenología espacial de la diversidad comunitaria intermareal en el norte de Chile: patrones comunitarios de variación geográfica e impacto de los procesos de extinción-recolonización post El Niño 82/83. Medio Ambiente 12:129-163

> Castilla JC, Camus PA (1992) The Humboldt-El Niño scenario: coastal benthic resources and anthropogenic influences, with particular reference to the 1982/83 ENSO. S Afr J Mar Sci 12:703-712

Colgan DJ, Byrne M, Rickard E, Castro LR (2005) Limited nucleotide divergence over large spatial scales in the asterinid sea star Patiriella exigua. Mar Biol 146:263-270

Cookson LJ (1991) Australasian species of Limnoriidae (Crustacea: Isopoda). Mem Mus Vic 52:137-262

> Cragg SM, Pitman AJ, Henderson SM (1999) Developments in the understanding of the biology of marine wood boring crustaceans and in methods of controlling them. Int Biodeterior Biodegrad 43:197-205

Crandall KA, Templeton AR (1993) Empirical tests of some predictions from coalescent theory with applications to intraspecific phylogeny reconstruction. Genetics 134: 959-969

Cunningham CW, Collins TM (1998) Beyond area relationships: extinction and recolonization in molecular marine biogeography. In: DeSalle R, Schierwater B (eds) Molecular approaches to ecology and evolution. Birkäuser Verlag, Basel, p 297-321

Davenport J, Stevenson TDI (1998) Intertidal colonization rates. A matched latitude, north v. south, remote v. near shore island experiment. Divers Distrib 4:87-92

Díaz JJ (1995) Zoogeography of marine gastropods in the southern Caribbean: a new look at provinciality. Caribb J Sci 31:104-121

> Donald KM, Kennedy M, Spencer HS (2005) Cladogenesis as the result of long-distance rafting events in South Pacific topshells (Gastropoda: Trochidae). Evolution 59: 1701-1711

Edgar GJ (1987) Dispersal of faunal and floral propagules associated with drifting Macrocystis pyrifera plants. Mar Biol 95:599-610

Edgar GJ, Burton HR (2000) The biogeography of shallowwater macrofauna at Heard Island. Pap Proc R Soc Tasman 133:23-26

> Excoffier L, Laval G, Schneider S (2005) Arlequin (version 3.0): an integrated software package for population genetics data analysis. Evol Bioinform Online 1:47-50

Feldberg MJ, Mix AC (2002) Sea-surface temperature estimates in the Southeast Pacific based on planktonic foraminiferal species; modern calibration and Last Glacial Maximum. Mar Micropaleontol 44:1-29

Folmer O, Black M, Hoeh W, Lutz R, Vriejenhoek R (1994) DNA primers for amplification of mitochondrial cytochrome c oxidase subunit I from diverse metazoan invertebrates. Mol Mar Biol Biotechnol 3:294-299
Fraser CI, Nikula R, Spencer HG, Waters JM (2009) Kelp genes reveal effects of subantarctic sea ice during the Last Glacial Maximum. Proc Natl Acad Sci USA 106: 3249-3253

- Fraser CI, Nikula R, Waters JM (2011) Oceanic rafting by a coastal community. Proc Biol Sci 278:649-655

Grantham TA (1995) Hierarchical approaches to macroevolution: recent work on species selection and the 'Effect Hypothesis'. Annu Rev Ecol Syst 26:301-321

> Hart MW, Keever CC, Dartnall AJ, Byrne A (2006) Morphological and genetic variation indicate cryptic species within Lamarck's little sea star, Parvulastra (=Patiriella) exigua. Biol Bull (Woods Hole) 210:158-167

Haye PA, Marchant S (2007) Newly developed PCR primers for polymorphic microsatellite loci from the marine isopod Limnoria sp. Mol Ecol Notes 7:1245-1247

Helmuth B, Veit RR, Holberton R (1994) Long-distance dispersal of a sub-antarctic brooding bivalve (Gaimardia trapesina) by kelp-rafting. Mar Biol 120:421-426

Henzler CM (2006) Rafting and refugia in North Atlantic amphipods: understanding the effects of Pleistocene climate change on low-dispersal marine species. $\mathrm{PhD}$ thesis, Duke University, Durham, NC

Hill CL, Kofoid CA (1927) Marine borers and their relation to marine construction on the Pacific coast. Final report of the San Francisco Bay Marine Piling Committee, National Resources Council, San Francisco, CA

Hinojosa I, González E, Ugalde P, Valdivia N, Macaya E, Thiel M (2007) Distribución y abundancia de macroalgas flotando a la deriva y su fauna peracarida asociada en los canales de la XI región, Chile. Cienc Tecnol Mar 30: $37-50$

> Hinojosa IA, Rivadeneira MM, Thiel M (2011) Temporal and spatial distribution of floating objects in coastal waters of central-southern Chile and Patagonian fjords. Cont Shelf Res 31:172-186

> Ho SYW, Phillips MJ, Cooper S, Drummond AJ (2005) Time dependency of molecular rate estimates and systematic overestimation of recent divergence times. Mol Biol Evol 22:1561-1568

> Ho SYW, Lanfear R, Bromham L, Phillips MJ, Soubrier J, Rodrigo AG, Cooper A (2011) Time-dependent rates of molecular evolution. Mol Ecol 20:3087-3101

Hobday AJ (2000) Persistence and transport of fauna on drifting kelp (Macrocystis pyrifera (L.) C. Agardh) rafts in the Southern California Bight. J Exp Mar Biol Ecol 253: 75-96

> Hoelzer GA, Drewes R, Meier J, Doursat R (2008) Isolationby-distance and outbreeding depression are sufficient to drive parapatric speciation in the absence of environmental influences. PLoS Comput Biol 4:e1000126

Ingólfsson A (1995) Floating clumps of seaweed around Iceland: natural microcosms and means of dispersal for shore fauna. Mar Biol 122:13-21

Jablonski D, Lutz RA (1983) Larval ecology of marine benthic invertebrates: paleobiological implications. Biol Rev Camb Philos Soc 58:21-89

- Johannesson K (1988) The paradox of Rockall: Why is the brooding isopod (Littorina saxatilis) more widespread than one having a planktonic larval dispersal stage $(L$. littorea)? Mar Biol 99:507-513

Johnson MW (1935) Seasonal migration of the wood-borer Limnoria lignorum (Rathke) at Friday Harbor, Washington. Biol Bull (Woods Hole) 69:427-438

Jones LG (1971) Studies on selected small herbivorous 
invertebrates inhabiting Macrocystis canopies and holdfasts in Southern California kelp beds. Nova Hedwigia Beih 32:343-367

Knowlton N, Weigt LA (1998) New dates and new rates for divergence across the Isthmus of Panama. Proc Biol Sci 265:2257-2263

Le Gac M, Féral JP, Poulin E, Veyret M, Chenuil A (2004) Identification of allopatric clades in the cosmopolitan ophiuroid species complex Amphipholis squamata (Echinodermata). The end of a paradox? Mar Ecol Prog Ser 278:171-178

Lefébure T, Douady CJ, Gouy M, Trontelj P, Briolay J, Gibert J (2006) Phylogeography of a subterranean amphipod reveals cryptic diversity and dynamic evolution in extreme environments. Mol Ecol 15:1797-1806

Lester SE, Ruttenberg BI, Gaines SD, Kinlan BP (2007) The relationship between dispersal ability and geographic range size. Ecol Lett 10:745-758

Librado P, Rozas J (2009) DNAsp v5: a software for comprehensive analysis of DNA polymorphism data. Bioinformatics 25:1451-1452

Macaya EC, Boltaña S, Hinojosa IA, Macchiavello JE and others (2005) Presence of sporophylls in floating kelp rafts of Macrocystis spp. (Phaeophyceae) along the Chilean Pacific Coast. J Phycol 41:913-922

Marin VH, Delgado LE (2007) Lagrangian observations of surface coastal flows North of $30^{\circ} \mathrm{S}$ in the Humboldt Current system. Cont Shelf Res 27:731-743

Marko PB, Hart MW (2011) The complex analytical landscape of gene flow inference. Trends Ecol Evol 26: $448-456$

Menzies RJ (1957) The marine borer family Limnoriidae (Crustacea, Isopoda). Part I: Northern and Central America: systematics, distribution and ecology. Bull Mar Sci Gulf Caribb 7:101-200

Menzies RJ (1962) The zoogeography, ecology and systematics of the Chilean marine isopods. Lunds Univ Arsskr NF 57:1-162

Miranda L, Thiel M (2008) Active and passive migration in boring isopods Limnoria spp. (Crustacea, Peracarida) from kelp holdfasts. J Sea Res 60:176-183

Nikula R, Reaser CI, Spencer HG, Waters JM (2010) Circumpolar dispersal by rafting in two subantarctic kelpdwelling crustaceans. Mar Ecol Prog Ser 405:221-230

Palero F, Abelló P, Macpherson E, Gristina M, Pascual M (2008) Phylogeography of the European spiny lobster (Palinurus elephas): influence of current oceanographical features and historical processes. Mol Phylogenet Evol 48:708-717

Posada D (2008) jModelTest: phylogenetic model averaging. Mol Biol Evol 25:1253-1256

Rogers AR (1995) Genetic evidence of a Pleistocene population explosion. Evolution 49:608-615

Rogers AR, Harpending H (1992) Population growth makes waves in the distribution of pairwise genetic differences.

Editorial responsibility: Philippe Borsa, Montpellier, France
Mol Biol Evol 9:552-569

Ronquist F, Huelsenbeck JP (2003) MRBAYES 3: Bayesian phylogenetic inference under mixed models. Bioinformatics 19:1572-1574

Rothäusler E, Gomez I, Hinojosa IA, Karsten U, Tala F, Thiel $M$ (2009) Effect of temperature and grazing on growth and reproduction of floating Macrocystis spp. (Phaeophyceae) along a latitudinal gradient. J Phycol 45: $547-559$

Sánchez R, Sepúlveda RD, Brante A, Cárdenas L (2011) Spatial pattern of genetic and morphological diversity in the direct developer Acanthina monodon (Gastropoda: Mollusca). Mar Ecol Prog Ser 434:121-131

Smith SDA (2002) Kelp rafts in the Southern Ocean. Glob Ecol Biogeogr 11:67-69

Svavarsson J (1982) Limnoria borealis (Isopoda, Flabellifera) and its commensal, Caecijaera borealis (Isopoda, Asellota), found in Icelandic waters. Sarsia 67:223-226

Swofford DL (2002) PAUP*. Phylogenetic Analysis Using Parsimony ( ${ }^{*}$ and other methods), Version 4.0. Sinauer Associates, Sunderland, MA

Tellier F, Meynard AP, Correa JA, Faugeron S, Valero M (2009) Phylogeographic analyses of the $30^{\circ} \mathrm{S}$ south-east Pacific biogeographic transition zone establish the occurrence of a sharp genetic discontinuity in the kelp Lessonia nigrescens: vicariance or parapatry? Mol Phylogenet Evol 53:679-693

- Thibert-Plante X, Hendry AP (2011) The consequences of phenotypic plasticity for ecological speciation. J Evol Biol 24:326-342

> Thiel M (2003a) Reproductive biology of Limnoria chilensis: another boring peracarid species with extended parental care. J Nat Hist 37:1713-1726

Thiel M (2003b) Extended parental care in crustaceans - an update. Rev Chil Hist Nat 76:205-218

Thiel M, Haye PA (2006) The ecology of rafting in the marine environment. III. Biogeographical and evolutionary consequences. Oceanogr Mar Biol Annu Rev 44: 323-429

Thiel M, Vásquez J (2000) Are kelp holdfasts islands on the ocean floor? - Indication for temporarily closed aggregations of peracarid crustaceans. Hydrobiologia 440:45-54

> Thompson JD, Higgins DG, Gibson TJ (1994) CLUSTAL W: improving the sensitivity of progressive multiple alignment through sequence weighting, position-specific gap penalties and weight matrix choice. Nucleic Acids Res 22:4673-4680

Vega JMA, Vásquez JA, Buschmann AH (2005) Population biology of the subtidal kelps Macrocystis integrifolia and Lessonia trabeculata (Laminariales, Phaeophyceae) in an upwelling ecosystem of northern Chile: interannual variability and El Niño 1997-1998. Rev Chil Hist Nat 78: 33-50

Waters JM, Roy MS (2004) Out of Africa: the slow train to Australasia. Syst Biol 53:18-24

Submitted: June 29, 2011; Accepted: February 10, 2012 Proofs received from author(s): May 5, 2012 